\title{
Intellectual Property Risks and Prevention of the Chinese Oversea Investment Under the Background of the Belt and Road Initiative
}

\author{
Lijing $\mathrm{Wu}$ \\ School of Humanities and Law \\ North China University of Technology \\ Beijing, China
}

\begin{abstract}
The Belt and Road strategy encourages a large number of Chinese enterprises to invest in countries along the belt and road. Compared with host countries, Chinese enterprises have certain advantages in terms of technology, and their intellectual property rights are important investment assets. During the investment process, intellectual property may face certain risks in the host country. In this regard, the international law can provide bilateral protection path, plurilateral protection path and multilateral protection path for intellectual property rights. Under the background of the Belt and Road, developed countries and developing countries should be differentiated and different legal strategies should be adopted to safeguard China's national interests. Enterprises should also take measures according to their specific conditions to guard against possible losses caused by intellectual property risks.
\end{abstract}

Keywords-the Belt and Road initiative; international investment; intellectual property

\section{INTRODUCTION}

In 2013, when visiting countries in Central Asia and Southeast Asia, the President Xi Jinping successively put forward the important initiatives including "Silk Road Economic Belt" and "21st Century Maritime Silk Road" (hereinafter referred to as "the Belt and Road") which attracted high attention rapidly. As the important policy of China to actively respond to the global trend, "the Belt and Road" brings huge opportunities for the economic development of China. Essentially, "the Belt and Road" belongs to the scope of international economic cooperation. And its implementation will change the innovation models and paths of different countries and regions and will reconfigure the innovation resources and capacities for different countries and regions. The Belt and Road strategy promotes the development of Chinese oversea investment. On the APEC Business Leader Submit, the President $\mathrm{Xi}$ Jinping indicated that the foreign investment of China in future 10 years will reach 1.25 trillion dollars which means that the foreign direct investment of China in future 10 years will be increased by near three times. The countries along the belt and road will undoubtedly become the important regions of oversea investment of China and the Chinese enterprises should realize the transformation from investment-driven mode to innovation-driven mode of the country during the process of going out. ${ }^{1}$ Therefore, in the field of oversea investment of China, the intellectual property is gradually becoming a kind of important investment assets. Because the countries along the belt and road are mostly developing countries which has relatively low protection level for intellectual property, China is facing special intellectual property risks in the oversea investment in countries along the belt and road.

\section{INTELLECTUAL PROPERTY RISKS FACED BY CHINA IN} THE OVERSEAS INVESTMENT IN COUNTRIES ALONG THE BELT AND ROAD

During the process of going out of Chinese enterprises, the intellectual properties may face following risks as one of investment assets.

\section{A. The Intellectual Property Cannot Be Admitted in Host Country}

Because of the regional characteristics of intellectual property, the intellectual properties obtained from capital exporting countries may not be recognized in such countries. And the reason why may be that the certification standards for intellectual properties of both countries are different and there are no bilateral and plurilateral intellectual property cooperation treaties between both countries and the both countries have not signed the intellectual property cooperation framework agreements or memorandum of understanding. It also may be that such intellectual properties, especially the patents or trademark rights have been applied or registered by others in host country. The issues on this regard are especially manifested in the issue of rush registration of brands such as the rush registration of Flying Pigeon Bicycle in Indonesia and the application and rush registration of brands including "Tongrentang", "Hongtashan", "Konka", "White Rabbit" and "Tianjin Guifaxiang 18th Street Fried Dough Twist" and other brands in Indonesia and the Philippines. ${ }^{2}$ There are also similar

Jin Liqun, Lin Yifu "The Belt and Road" Leading China [M] Beijing: China Literature and History Publishing House, 2015: 183-184.

$\mathrm{Gu}$ Lingyun. Analysis and Solution of Enterprise Intellectual Property Risks in Construction of Free Trade Zone under the Background of "the Belt and Road" [J]. The South China Sea Law Journal. 2018 (4):99. 
conditions in the field of patents. For example, Beijing Xiaomi Technology Co., Ltd was sued by Ericsson in India for infringement of patent in 2014 and Delhi Supreme Court of India finally supported the "interlocutory injunction" filed by Ericsson and forbidden Xiaomi to promote and sell the products be identified as infringement of patent in Indian market.

One of the most important reasons of generation of such risks is that the enterprises lack complete intellectual property layout and planning before going out and fail in timely and comprehensively understanding the protection of intellectual properties of destination countries, especially in the field of patent and brand with frequent infringement conditions.

\section{B. The Intellectual Property Cannot Be Fully Protected in Host Countries}

Quite a part of the investment of China in countries along the belt and road belongs to the situation of industry upgrading and transfer. One of the objectives of investment is to relieve the domestic excess production capacity. While the host countries of investment which are the receiving countries of industrial transfer are usually the countries with relatively low economic development level and such type of countries generally possess relatively low protection level for intellectual properties. The technologies of Chinese investment enterprises possess certain technological superiority and advancement in local places and their patented technologies may be stolen or counterfeited in host countries. Currently, the coordination and protection mechanism for bilateral or regional intellectual properties is still under construction. Once the patents or proprietary technologies are infringed, it will mainly rely on the administrative remedy or judicial remedy in host countries. While there are large differences on aspects including efficiency, transparency and justice, etc of host countries and it may not timely and effectively protect the intellectual properties of Chinese enterprises to just rely on the local remedy of host countries.

\section{The Intellectual Properties Face the Risks of Legal Transference or Government Regulation in Host Countries}

The intellectual property shall meet the specific conditions stipulated by laws and shall go through legal procedures before being recognized as those protected by law. Within the time and spatial range allowed by law, the obligee shall possess the rights of exclusivity and exclusiveness of intellectual properties, therefore the essence of intellectual properties is a kind of balance and compromise between personal rights and public social interests. Such balance may be changed due to the changes in policies and laws of host countries, such as the change of conditions for patent application or granting conditions which may cause the patent right of investment enterprise to be invalid. For another example, the government of host country takes compulsory license measure for the patent right of investment enterprise in consideration of maintenance of public interests which may cause harm the interests of obligee. In recent years, there have been related disputes in ICSID. The investors think that the conducts of government of host country violate the fair and equitable treatment and violate the reasonable expectation of investment environment based on the fair and equitable treatment articles in the bilateral investment protection treaty and even claim that the conducts of government of host country indirectly constitute the indirect expropriation. However, from the arbitration result, the claims of investors usually cannot be admitted by the investment arbitration court and their interests cannot be effectively protected through the mode of investment arbitration. ${ }^{3}$ The intellectual properties in international investment require international cooperation mechanism to obtain effective protection.

\section{ANALYSIS OF PROTECTION PATHS FOR INTELLECTUAL PROPERTIES IN INTERNATIONAL INVESTMENT}

Unlike the common property rights, the intellectual properties possess regional characteristics on the legal aspect, therefore the intellectual properties in the field of international investment involve the issue of recognition and protection in international laws. For this end, the international society formulates international agreements of different levels with different contents by joint efforts to establish the multiple protection paths for intellectual properties in the international investment. Currently, the international protection paths for the intellectual properties in investment field in the international treaty legal system can be divided into following types.

\section{A. Bilateral Protection Path}

The bilateral paths in the protection of intellectual properties in international investment are mainly manifested as Bilateral Investment Treaty (hereinafter referred to as BIT). The basic system arrangement for intellectual property protection of BIT is to list the property in the protected asset list in the definition of "investment (asset)". Its direct legal consequence is that the BIT general investment protection rules are integrally applied to the protection of various kinds of investment assets (including intellectual property). BIT mainly protects intellectual property investment from illegal interference and unfair treatment of measures of government of host country and it can comply with the logic of investment protection. ${ }^{4}$

The contents of BIT can be determined according to the specific requirements of both parties of the negotiation which can be relatively flexible. Therefore, the developed countries in Europe and America and other regions have been relying on BIT to adopt various kinds of strategies in recent years to lead the international protection system for intellectual properties to develop towards the direction of high standard, broad scope and strong restriction within the international range which causes important reform to the contemporary intellectual protection system. $^{5}$

\footnotetext{
Study of Disputes over Intellectual Property Investment [J]. International Law Review of Wuhan University 2017(4) 31-45.

$4 \quad$ Zhang Jianbang. Study on Modern Transformation for Intellectual Property in International Investment Treaty [J]. China Legal Science, 2013 (4): $64-65$

$5 \quad$ Wang Liwu, Yang Liu. Impacts of Bilateral Investment Agreement on International Protection System for Intellectual Property and Solution [J] Journal of UEST of China (social science edition), 2013 (6): 47.
} 


\section{B. Plurilateral Protection Paths}

Since 1990s, the trend of regional economic integration has become obvious. Many countries signed Regional Trade Agreement (hereinafter referred to as RTA) or Free Trade Agreement (hereinafter referred to as FTA) which all contain the contents of intellectual property protection and therefore impact the intellectual property legal system of contracting states. And such impacts involve the legislation for intellectual property, the performance of treaty obligations, intellectual property right law enforcement, the implementation of domestic policies and national resource distribution as well as other aspects of contracting states. Because such regional treaties are signed by part of the countries upon negotiation, the author refers to the concept in plurilateral agreements in the WTO legal agreement framework and names it as the plurilateral protection path of intellectual property.

For the reason of WTO system, in recent years, it has been difficult for WTO to pass new multilateral legal agreement. Therefore, various countries successively signed regional agreements as the supply of international systems. In RTA or FTA, there are special restriction stipulations or exceptions on intellectual properties on the basis of existing international legal systems which manifest the special contents for protection of intellectual properties that are never in the past investment agreements. Such special protection contents involve the non-discriminatory treatment, performance requirements, levy and other investment protection rules. 67

\section{Multilateral Protection Paths}

The multilateral protection paths for intellectual properties in international investment mainly refer to the Agreement on Trade-Related Aspects of Intellectual Property Rights (hereinafter referred to as TRIPs) in WTO legal framework. TRIPs stipulates the basic principles of international protection for intellectual properties, including principle of national treatment, most-favored-nation treatment principal and public interest protection principle, etc and stipulates the general obligations of member countries: the members shall guarantee that their domestic laws can provide the various executive routines stipulated in the agreement; the executive routines of related intellectual properties shall be fair and just; the resolution of cases shall be written and go through discussion; such resolutions shall be based on evidences with the opportunities for hearing of witnesses of all parties involved; the parties involved shall have the opportunity to submit the final administrative resolution and the legal issues to the judicial authority for review. ${ }^{8}$ Although the above stipulations are to adjust the intellectual properties in international trades, TRIPs constructs the multilateral legal structure of international protection for intellectual properties and provides the integrated standards for protection of intellectual properties so as to become the legislative basis and reference for

6 Fan Jing, Yi Shuling. Analysis of International Economic Treaties related to Protection of Intellectual Property in International Investment [J]. Journal of Yantai University (philosophy and social science edition) 2015 (1): 36.

Same with note 1, 65-67

TRIPs, Article 41, Tian Xiaoyun, International Economic Law [M]/ Beijing: Law Press 2016: 235-236. international protection of intellectual properties in the field of international investment.

\section{Contrastive Analysis of Protection Standards for Intellectual Properties in International Investment}

In the various types of protection paths mentioned above, in term of the protection standards, the TRIPs standard of WTO is the basis and other plurilateral and bilateral agreements provide higher protection requirements on this basis which is called the "TRIPs-plus" rules in later TRIPs era by the theoretical cycle. The TRIPs-plus rules mainly include following conditions: (1) stipulations aiming at the issues not involved in TRIPS; (2) set up obligations higher that those in TRIPs by aiming at the existing stipulations in TRIPs; (3) cancel the flexibility and convert it into compulsive obligations by aiming at the authorization articles permitted by TRIPs. ${ }^{9}$

The reason why there are the "TRIPs-plus" rules for intellectual property protection in the bilateral and plurilateral investment treaty is that the TRIPs agreement fails in completely meeting the increasing intellectual property protection requirements of developed countries. For this end, the European and American developed countries select BIT and FTA where it will be easier for them to realize the interest objectives as the important tools for promotion of their national strategies of intellectual property which poses huge challenges to the developing countries including China. Therewith, we should analyze rationally and respond calmly.

\section{SugGestions on SOlutions to Protection OF INTELLECTUAL PROPERTIES IN INTERNATIONAL INVESTMENT FIELD OF CHINA}

\section{A. Suggestions on Government Level}

Currently, China has become the second largest foreign investment country in the world and ${ }^{10}$ ranks third place in the amount of investment attracted. ${ }^{11}$ At the same time, China is implementing the intellectual property strategy; therefore the issue of intellectual property protection in the field of international investment shall be brought to attention. The international intellectual property protection in the field of international investment is mainly realized through bilateral and plurilateral paths. When signing foreign treaties, our country shall make a difference between developed and developing countries. As for the developed countries, China is generally in the status of capital importing country while the developed countries usually promote the strong protection of intellectual protection. When signing investment treaties with developed countries, we shall set up necessary exception clauses and reserve systems and stress to respect the public administration rights, public orders and public security of the host countries. Aiming at the developing countries, especially the countries along the belt and road, China is mainly in the

\footnotetext{
Zhang Ping. Intellectual Property Law [M]. Beijing: Peking University Press 2015: 25.

10 UNCTAD, World Investment Report2017 (Geneva, United Nations Publication2017)14.

11 UNCTAD, World Investment Report2017 (Geneva, United Nations Publication2017)12.
} 
status of capital exporting country. And we should take the maintenance of the obligations and flexibility of current multilateral intellectual property agreements as center and intensify the construction and improvement of dispute settlement mechanism between investors and host countries when constructing intellectual property protection systems in the investment treaty and framework agreements.

\section{B. Suggestions on Enterprises}

The enterprises invested by China in countries along the belt and road shall conduct thorough legal due diligence to the host countries, improve the intellectual property layout and prevent the risk where the intellectual properties may not be admitted by host countries so as to protect their own intellectual properties. Secondly, aiming at the issue of relatively weaker protection efforts for intellectual properties of host country, the Chinese technology enterprises shall make it difficult for competitors in market countries to master the core patents for constituting products as far as possible to prevent the complete patented technologies to be easily copied. A complete patented product integrates multiple parallel or mutually constrained multiple patented technologies. The enterprises can classify the product items into multiple function modules in details as far as possible during $\mathrm{R} \& \mathrm{D}$ process and deliver to different $\mathrm{R} \& \mathrm{D}$ networks for completion and then the subsidiaries or individual of enterprise shall apply for patent and the various patents will finally be delivered to the integrated system to form the product. Finally, the risks including changes of laws and policies of host country or administrative measures such as compulsory license, etc adopted by the government of host country belong to traditional political risks which can be spread through oversea investment insurance system so as to timely make up the economic losses of enterprises.

\section{CONCLUSION}

The belt and road is the national top strategic design and layout. The investment in countries along the belt and road can deepen the International capacity cooperation, drive the output of domestic advantageous capacity, high-quality equipment and applicable technology, promote the capacities of China in technological $\mathrm{R} \& \mathrm{D}$, production and manufacturing and make up the shortage in energy resources in China so as to promote the quality improvement and upgrading of related industries of China. And the realization of above targets cannot be done without the protection of related intellectual properties. The intellectual properties have become a national strategy. During the process of guiding oversea investment, we should stress more to comply with the intellectual property legal norm and prevent the intellectual property legal risks. Only in this way can the oversea investment plays positive functions in motivate the technical communication, enriching resource and energy supply channels, promoting global market system construction, promoting the flow and optimal configuration of element resources in the world, increasing the friendly relationship and joint development with cooperation countries and other fields.

\section{REFERENCES}

[1] Jin Liqun, Lin Yifu "The Belt and Road" Leading China [M] Beijing: China Literature and History Publishing House, 2015: 183-184.

[2] Gu Lingyun. Analysis and Solution of Enterprise Intellectual Property Risks in Construction of Free Trade Zone under the Background of "the Belt and Road" [J]. The South China Sea Law Journal. 2018 (4):99.

[3] Study of Disputes over Intellectual Property Investment [J]. International Law Review of Wuhan University 2017(4) 31-45.

[4] Zhang Jianbang. Study on Modern Transformation for Intellectual Property in International Investment Treaty [J]. China Legal Science, 2013 (4): 64-65

[5] Wang Liwu, Yang Liu. Impacts of Bilateral Investment Agreement on International Protection System for Intellectual Property and Solution $[\mathrm{J}]$ Journal of UEST of China (social science edition), 2013 (6): 47.

[6] Fan Jing, Yi Shuling. Analysis of International Economic Treaties related to Protection of Intellectual Property in International Investment [J]. Journal of Yantai University (philosophy and social science edition) 2015 (1): 36.

[7] Jin Liqun, Lin Yifu "The Belt and Road" Leading China [M] Beijing: China Literature and History Publishing House, 2015: 65-67

[8] TRIPs, Article 41, Tian Xiaoyun, International Economic Law [M]/ Beijing: Law Press 2016: 235-236.

[9] Zhang Ping. Intellectual Property Law[M]. Beijing: Peking University Press 2015: 25.

[10] UNCTAD, World Investment Report2017(Geneva, United Nations Publication2017)14.

[11] UNCTAD, World Investment Report2017(Geneva, United Nations Publication2017)12. 